\title{
The Effect of Covid-19 on the Service, Manufacturing, and Construction Sectors in Ethiopia: A Case Study in the Gurage Zone
}

\author{
Lemma Shallo \\ Department of Economics, Wolkite University \\ Simachew Alemneh \\ Department of Marketing Management, Wolkite University \\ Endalkachew Kabtamu \\ Department of Economics, Wolkite University
}

\begin{abstract}
This study investigates the socioeconomic effects of COVID-19 on service, manufacturing and construction sectors and its mitigating strategies in Ethiopia using case study in Gurage zone. It comprises a total of 390 households. Both simple random and purposive sampling techniques were used to select sample households. The data analysis employed descriptive statistics and narrative methods. The results of the study exhibited that the crises brought adverse effects on the people who employed and invested in the service, manufacturing, and construction sectors. The consequences to employed labors include psychological, social and economic, which have harmfully disturbed their lives, whereas business owners have faced significant sum of reductions in revenues, orders, and workforce. In addition, the businesses faced a high shortage of raw materials, limited access to the transportation of goods, decrease in the number of customers, and expiration of goods during the crises. This suggests that the government and policymakers should lay down social protection programs, facilitate credit support and promote solidarity among people to confront the adverse effects of the COVID-19 pandemic.
\end{abstract}

Keywords: COVID-19 Pandemic, Business Owner, Labor, Gurage Zone

DOI: $10.7176 /$ IEL/12-1-03

Publication date: January $31^{\text {st }} 2022$

\section{Introduction}

Since the first infections in China at the end of 2019, the Coronavirus disease 2019 (COVID-19) has continued to spread across the world. The world economy is experiencing a historic and unprecedented shock as the pandemic triggers several shocks simultaneously including health, supply, demand, and financial shocks (Triggs \&Kharas, 2020; Goshuet al., 2020). The pandemic is a global concern so it needs the coordinated solidarity of people, countries, regions, and continents to ensure that the planet we live on is the safest place for humankind. Many scholars conjectured that the incidence of the COVID-19 pandemic bring astonishing effects on the economic, social, political, and technological shape of countries and the globe at large. In addition to the socio-economic and political impact, the outbreaks of pandemics make human existence on the planet earth under question. Due to the outbreak of the COVID-19 pandemic, trade in goods and services is declining globally and domestically, movement of people is limited, unemployment is rising, remittances are slashing, education institutions have been lockdown, and hotels, tourism, and transport services are decreasing, GDP is projected to be declining, and many other concerns are happening. As a developing country, Ethiopia strives to attain economic, social, and political development. During the last two decades, it has achieved a lot of economic progress that contributed to poverty reduction. Unluckily, the nation faced the COVID-19 pandemic which could be a challenge for the gained development. The emergence of Coronavirus, which is a global challenge, has posed a socio-economic threat. Unless it is curbed through coordinated efforts, the consequence might be unpredictable. In Ethiopia, the first case of the pandemic was reported on March 13, 2020. As a result, different measures were taken by the government, such as, education institutions were closed, transport partially locked, and most civil servants especially vulnerable workers (old age, pregnant and child-caring women, and others) were allowed to stay home. Furthermore, public events (sports, cinemas, ceremonies, etc) were banned, the number of people in meetings and hotels was limited to four, and passengers on transports were reduced by half. These measures have their effect on the economy and social interaction (markets, living style, Idir, Equb, etc) of the nation.

Societies with lower economic status are more vulnerable to the COVID-19 pandemic, which is further complicated by economic and social welfare hardships (ILO, 2020). This depresses productivity and raises health care costs, leading to increased poverty. This is a "disease-driven poverty trap". From an economic perspective, the key issue is not just the number of cases of the COVID-19, but the level of disruption to economic activities which in turn aggravate the level of health risks. According to Ethiopian Economic Association (EEA, 2020), the 
pandemic triggers several shocks simultaneously such as health, supply, demand, and financial shocks. Efforts by governments to control the COVID-19 pandemic through partial and full business closures unavoidably lead to a general decline in economic activities domestically and globally. From an economic perspective, the key issue is not just the number of cases of the COVID-19, but the level of disruption to economic activities which in turn aggravates the level of health risks. In general, the effect of a decline in economic growth would make massive disruption in various sectors. Within this context, it is necessary to investigate the economic and social impacts of the COVID-19 pandemic on service, manufacturing and construction sectors in Ethiopia and more specifically in the study area, that is, the Gurage zone.

It is presumed that the effects of the pandemic depend on the period taken to control the pandemic i.e., the more protracted time to control the pandemic the more its effects will be, and the lesser the time the lesser its effect will be. This suggests that countries should not give time to control the spread of the pandemic; they should work strongly to shorten the time and lessen its economy-wide and socio-political effects. For instance, at present time China controls the contagion so that its success can serve as a lesson for other countries. Although the eruption of the pandemic brought upsetting effects to all countries, its effects and spread vary across countries. Previously economically weak countries are highly affected by the pandemic and run into recession (Weber, 2020). Also, we argued that the spread and socio-economic effects of the virus could higher in these countries due to the following reasons. Early shreds of evidence on the health and economic implications of COVID-9 revealed that even if the health effect is generally similar in all countries, the extent of the health damage and the effectiveness of the public health measures and, thereby, the economic damage depend on the country context. The effectiveness of health measures such as social distancing, lockdown, self-isolation, and staying at home depends on the social and economic situation of the country. In this respect, the economics of externality and incentive plays an essential role in the effectiveness and efficiency of these public health measures. The fact that contagious diseases such as COVID-19 are rife with "negative externalities" means that the actions of each individual affect the whole system of containing or suppressing the virus. For instance, the youth, who accounts for at least $70 \%$ of the Ethiopian population, are more likely to be infected and become a carrier of the virus but they are less likely to die. Thus, these low-risk category individuals have low incentives to self-isolate or take precautionary measures (Weldesilassie and Woldehanna, 2020).

In Ethiopia, preliminary estimations suggest, over the next 3 months, 1.41 mill jobs are threatened using a medium-estimate (low-estimate 727 thousand, high-estimate 2.5 mills), and an income loss for urban selfemployed in services at \$265 mill, using a medium-estimate (low-estimate \$132 Mill, high-estimate \$296 mill) (JCC, 2020). In urban Ethiopia, only $12 \%$ of the labor force is employed in the manufacturing sector and earns their income on regular basis. The majority are temporarily employed, self-employed, or work in the informal sector and earn their income on daily basis. For instance, a recent survey on Micro, Small and Medium businesses enterprises (MSE) operated in 8 big cities in Ethiopia shows that these businesses generated jobs for more than 150,000 workers in these cities (26). The same survey report shows that of these, $72 \%$ are paid workers and $77 \%$ are temporary employees. The average monthly income (after tax) of workers employed in these businesses is 2069 Birr (or USD 96), which makes them above the poverty line (Weldesilassie and Woldehanna, 2020). There are few studies conducted about the socio-economic effects of the COVID-19 pandemic. Some of these are Goshu et al. (2020), Forsido et al. (2020), JCC (2020), Weldesilassie and Woldehanna (2020), and so on. However, most of these studies are focused on preliminary assessments and didn't show the genuine socio-economic effects ofCOVID-19 pandemic on the economy and different sectors. Thus, this study filled the gap and tried to investigate the socio-economic effects of the COVID-19 pandemic on the service, manufacturing, and construction sectors in the Gurage zone. The general objective of the study was to investigate the socio-economic effects of the Coronavirus disease 2019 (COVID-19) pandemic on service, manufacturing, and construction sectors in the study area, Gurage zone.

\section{Materials and Methods}

The study is conducted in the Gurage zone located in the southwestern and northernmost part of the region of the SNNPRS. It is bounded by Siltie in the southeast and Hadia zone and Yem special district in the south and southwest, respectively. The northern, western, and eastern parts are sharing a border with Oromia. According to CSA (2013) population projection, the total number of people in the zone is estimated at 1,597,360 in 2016 (48.5\% male and $51.5 \%$ female). The majority $(84.9 \%)$ live in the rural area depending on agriculture as means of livelihood. It falls into three agro-ecological zones, that is, dega, weinadega and kola. The study is a cross-sectional survey design that has employed both quantitative and qualitative data types. The quantitative approach was used for statistical analysis of household data collected through a survey questionnaire; whereas, the qualitative approach was used to include subjective assessment of attitudes and opinions of households and key personnel informants in the study area. The study used both primary and secondary data sources. The primary data were gathered from sample respondents whereas, the relevant secondary data were collected from different published and unpublished sources including books, journal articles, official reports and records, magazines, and the internet 
which are relevant to the topic under study. Data were obtained through personally administered questionnaires that would be prepared based on a literature review to address research questions. The data collection instrument was developed in the way they measure the study objectives, evaluated by experts, and pretested before the collection of actual data.

In collecting the pertinent data, various mixes of probability and non-probability sampling techniques were employed. Although service, manufacturing, and construction sectors are everywhere in the zone, six study areas (three districts and three town administrations) were purposefully selected for this study, where the aforementioned sectors are mainly concentrated. These are Ezha, Gumer, Mihuraklil districts, and Wolkite, Butajira, and Endibir towns. Moreover, the underlying assumption of choosing these districts and towns was that spread of the pandemic might be high as a result of its associated socio-economic interactions. These areas are deemed to have high population densities compared to other districts and towns in the zone so that the researchers can acquire rich information about the study subject. The sample respondents were selected randomly from sectors (service, manufacturing, and construction) of the study areas. The key informant interview (KII) participants were selected purposively, and these informants who are deemed to have rich information about the subject were interviewed. A maximum of 40 key informants were chosen from different offices and sectors six selected study areas and Gurage zone. These offices and sectors include culture and tourism offices, trade and enterprise offices, Job creation and employment offices, transport offices, finance, and economic development offices, small and medium enterprises, Urban and construction offices, districts, and town administrators and experts. For survey questionnaires, after determining the sample size, it is proportionately allocated for each sector, and selected districts and towns. According to Yamane (1967), the formula for sample size determination for this study is calculated as:

$$
n=\frac{N}{1+N(e)^{2}}
$$

Where, $\mathrm{N}$ denotes the total target population, $\mathrm{n}$ is the sample size, and e is the margin of tolerable error at $5 \%$. Thus, for $\mathrm{N}=\mathrm{xxx}$, the sample size (n) become:

$n=\frac{16264}{1+16264(0.05)^{2}} \approx 390$

Then, the sample size was allocated into each sector (service, manufacturing and construction) as demonstrated in table 3.1.

Table 1: Sample Size Distribution to the Three Sectors

\begin{tabular}{llccc}
\hline S.no & Target Respondents & Number of Enterprise & Total population & Sample Size \\
\hline 1. & Service Sector & 1211 & 6402 & 223 \\
2. & Manufacturing sector & 768 & 4069 & 74 \\
3. & Construction sector & 1070 & 5793 & 93 \\
Total & & $\mathbf{3 0 4 9}$ & $\mathbf{1 6 2 6 4}$ & $\mathbf{3 9 0}$ \\
\hline
\end{tabular}

Source: Compiled from Gurage Zone Enterprise and Job Creation Office (2020)

The first stage of data analysis was data cleaning. Questionnaires had been examined to ensure they were completed and consistently filled. The data collected were analyzed from the entire sample. Depending on the objectives of the study, descriptive statistics, narration, and document analysis methods were used for the analysis of quantitative data. The descriptive statistics include percentages, mean, variance, standard deviation, frequency distribution, and graphs. The socio-economic characteristic of sample respondents was compared using t-tests for continuous and chi-square $\left(\chi^{2}\right)$ test for discrete variables. Qualitative information from key informant interviews (KII) and focus group discussion (FGD) was analyzed through narration.

\section{Result and Discussion}

This study was conducted to assess the socio-economic effects of COVID-19 in the service, manufacturing, and construction sectors found in the Gurage Zone. It then conducted a survey study to assess the effects on the performance of the service, manufacturing, and construction sectors. The study also prompted to identify challenges and opportunities; as well as proposing mitigating strategies to avert the socio-economic impact of COVID-19 in these sectors. The survey questionnaire was distributed to 390 respondents of which 162 were workers and 228 were business owners.

\subsection{Respondents Background Information}

About 115 (50.4\%) of business owners were engaged in the service sector; while 69 (30.3\%) and 44 (19.3\%) were involved in the construction and manufacturing sectors, respectively. Similarly, the majority of workers $(64.5 \%)$ were employed in the service industry; while $19.7 \%$ and $15.8 \%$ of workers were manufacturing and construction workers, respectively. Regarding their gender, male respondents accounted for $74.6 \%$ of business owners and $72.8 \%$ of workers, while the rest covers females' share. In total, the study involved $26.2 \%$ of female and $73.8 \%$ of male respondents. The age composition of respondents indicated that about $54.6 \%$ were within the 
age group of $26-35,22.6 \%$ were included in the age range of $36-45$ and $17.2 \%$ of them were represented in the age group of 18-25. Looking into education level, the major share of the respondents 203 (52.1\%)were graduates of tertiary education, while about $119(30.5 \%), 53(13.5 \%$, and $15(3.8 \%)$ of the respondents constitute high school level and grade 1-8 class level education levels, respectively. Very few respondents, 15(3.8\%), from the worker's group were found illiterate and had been guided to respond to the survey questions. Furthermore, it was found that about $72.6 \%$ of the respondents were married while the rest constitute single. The household sizes of the sample households ranged from 1 to 10 with an average size of 4 persons. The average household sizes of the sample business owner and worker households were about 4 and 3 persons, respectively.

Table 2: Summary of Sample Households' Background Information

\begin{tabular}{|c|c|c|c|c|c|c|c|}
\hline \multicolumn{2}{|c|}{ Respondent background } & \multicolumn{2}{|c|}{ Business Owners } & \multicolumn{2}{|l|}{ Workers } & \multicolumn{2}{|l|}{ Total } \\
\hline & & Frequency & Percent & Frequency & Percent & Frequency & Percent \\
\hline \multirow{3}{*}{$\begin{array}{l}\text { Sectors individual } \\
\text { is engaged in }\end{array}$} & Service & 115 & 50.4 & 108 & 66.7 & 223 & 57.2 \\
\hline & Manufacturing & 44 & 19.3 & 30 & 18.5 & 74 & 19.0 \\
\hline & Construction & 69 & 30.3 & 24 & 14.8 & 93 & 23.8 \\
\hline \multirow{2}{*}{ 芦西 } & Female & 58 & 25.4 & 44 & 27.2 & 102 & 26.2 \\
\hline & Male & 170 & 74.6 & 118 & 72.8 & 288 & 73.8 \\
\hline \multirow{2}{*}{ 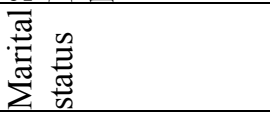 } & Single & 66 & 28.9 & 41 & 25.3 & 107 & 27.4 \\
\hline & Married & 162 & 71.1 & 121 & 74.7 & 283 & 72.6 \\
\hline \multirow{5}{*}{ 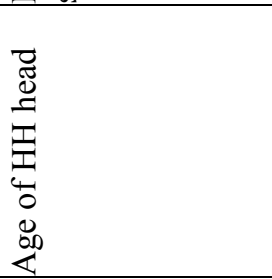 } & $18-25$ & 28 & 12.2 & 39 & 24.1 & 67 & 17.2 \\
\hline & $26-35$ & 107 & 46.9 & 106 & 65.4 & 213 & 54.6 \\
\hline & $36-45$ & 71 & 31.1 & 17 & 10.5 & 88 & 22.6 \\
\hline & $46-55$ & 15 & 6.8 & & & 15 & 3.8 \\
\hline & $56-65$ & 7 & 3.0 & & & 7 & 1.8 \\
\hline \multirow{4}{*}{ 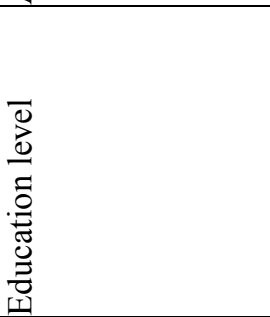 } & Illiterate & 1 & 0.4 & 14 & 8.6 & 15 & 3.8 \\
\hline & 1-8 grade levels & 42 & 18.4 & 11 & 6.8 & 53 & 13.6 \\
\hline & 9-12 grade levels & 57 & 25.0 & 62 & 38.3 & 119 & 30.5 \\
\hline & $\begin{array}{lr}\text { Graduates } & \text { of } \\
\text { higher institutions } \\
\text { (college } \\
\text { university) }\end{array}$ & 128 & 56.2 & 75 & 46.3 & 203 & 52.1 \\
\hline \multirow{10}{*}{ 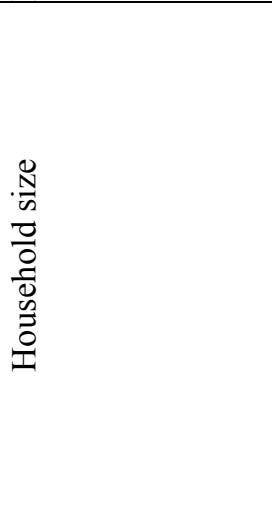 } & 1 & 52 & 22.8 & 38 & 23.5 & 90 & 23.1 \\
\hline & 2 & 7 & 3.1 & 17 & 10.5 & 24 & 6.2 \\
\hline & 3 & 29 & 12.7 & 27 & 16.6 & 56 & 14.4 \\
\hline & 4 & 43 & 18.9 & 32 & 19.8 & 75 & 19.2 \\
\hline & 5 & 23 & 10.1 & 35 & 21.6 & 58 & 14.9 \\
\hline & 6 & 41 & 18.0 & 0 & 0.0 & 41 & 10.5 \\
\hline & 7 & 21 & 9.2 & 0 & 0.0 & 21 & 5.4 \\
\hline & 8 & 5 & 2.2 & 13 & 8.0 & 18 & 4.6 \\
\hline & 9 & 4 & 1.8 & 0 & 0 & 4 & 1.0 \\
\hline & 10 & 3 & 1.4 & 0 & 0 & 3 & 0.8 \\
\hline
\end{tabular}

Source: (Survey Questionnaire, 2021)

\subsection{Socio-Economic Effects of COVID-19 on Business Operations of Service, Manufacturing and Construction Sectors}

As it has appeared everywhere, the socio-economic effects happening due to the novel coronavirus (COVID-19) are unprecedented in Ethiopia and specifically in the study area, the Gurage zone. This study indicated that the COVID-19 crises highly affected the workers' lifestyle and business owners' operations significantly in the three sectors, namely service, manufacturing, and construction sectors. As indicated in the table below it was found that $60(25.4 \%)$ of business owners were stopped their operations because of the current COVID-19. However, the majority of the respondents $176(74.6 \%)$ were continued their operations despite the challenges they faced. Among 
the halted business, about $78 \%$ were temporarily stopped because of COVID-19 cases in their business; and only $10 \%$ were halted because of instructions by authority. Some $8.5 \%$ of businesses were stopped due to reduced orders. The result showed that the majority of businesses were stopped by their own decisions due to COVID-19 cases encountered in their business; not necessarily waiting for authority's instruction to close businesses.

Table 3: Effect of COVID-19 on Business operations

\begin{tabular}{|c|c|c|c|}
\hline & & Frequency & Percent \\
\hline \multirow{3}{*}{$\begin{array}{l}\text { Have you stopped } \\
\text { operation because of } \\
\text { current COVID-19? }\end{array}$} & No & 176 & 74.6 \\
\hline & Yes & 60 & 25.4 \\
\hline & Total & 236 & 100.0 \\
\hline \multirow{5}{*}{$\begin{array}{l}\text { If your answer is Yes, } \\
\text { what is the current status } \\
\text { and subsequent reasons? }\end{array}$} & $\begin{array}{l}\text { temporarily stopped because of COVID-19 cases in } \\
\text { our business }\end{array}$ & 46 & 78.0 \\
\hline & temporarily stopped because of reduced orders & 5 & 8.5 \\
\hline & $\begin{array}{l}\text { temporarily stopped because of instructions by } \\
\text { authorities }\end{array}$ & 6 & 10.2 \\
\hline & $\begin{array}{l}\text { stopped operations previously but currently running } \\
\text { again }\end{array}$ & 1 & 1.7 \\
\hline & Total & 58 & 98.4 \\
\hline
\end{tabular}

\section{Source: (Survey Questionnaire, 2021)}

It was found that there were considerable numbers of businesses shutdowns. Most businesses were continued to perform their businesses even though they faced difficulties during the outbreak of the pandemic. These businesses were found to have lost revenues, decreased orders, and absentees of the required workforce. Hence, businesses were not operating at their full capacity during the crisis. The businesses' reply to such impact was presented in the table below. Almost $93 \%$ of businesses reported that they have encountered a reduction in their business revenue, out of which $125(53 \%)$ of them had encountered $25-50 \%$ revenue cut during the COVID crisis. Nearly $31 \%$ of businesses also faced $0-25 \%$ reduction in revenue. Few businesses also faced severe impact in their revenue cut estimated from $50-100 \%$ business loss. This implies that the COVID-19 pandemic adversely impacted the revenues of businesses in the service, manufacturing, and construction sectors. This finding is in line with the result found by Goshuet al.(2020). They discussed that the manufacturing, construction, and service sectors face a high reduction in revenue under mild and severe scenarios. Despite the impact on revenue, $118(50 \%)$ of businesses were not faced difficulty in delivering orders. Whereas, $48(20 \%)$ of businesses had failed to deliver orders for $0-25 \%$ of orders; and also 57 (24\%) of businesses were not able to complete and deliver $25-50 \%$ of the orders. Few, $13(5.5 \%)$ of the businesses were almost incapable to deliver $50-100 \%$ of their orders. A study by Forsidoet al. (2020) stated that orders for food products have been canceled due to the pandemic. On the other hand, the sample business owners were asked about the impact of COVID-19 on the workforce during the crises. Accordingly, about 80 (34\%) of them had faced no problem concerning the number of employees during the crises. However, the rest of the sample households had confronted serious challenges about the workforce, such as 72 (31\%), $61(26 \%)$, and $17(7 \%)$ had lost $0-25 \%, 25-50 \%$, and $50-100 \%$ of their workforce, respectively.

Table 4: Effect of COVID-19 on business revenue, order and workforce

\begin{tabular}{|l|l|l|l|l|l|l|}
\hline \multirow{2}{*}{ Impact Level } & \multicolumn{2}{l}{$\begin{array}{l}\text { What has been the impact of } \\
\text { COVID-19 crisis on the revenue } \\
\text { of the organization until now? }\end{array}$} & $\begin{array}{l}\text { Impact of COVID-19 on } \\
\text { orders delivery until now }\end{array}$ & \multicolumn{2}{l|}{$\begin{array}{l}\text { Impact of COVID-19 on } \\
\text { workforce until now }\end{array}$} \\
\cline { 2 - 8 } & Frequency & Percent & Frequency & Percent & Frequency & Percent \\
\hline None & 16 & 6.7 & 118 & 50.0 & 80 & 33.9 \\
\hline $0 \%-25 \%$ & 72 & 30.5 & 48 & 20.3 & 72 & 30.5 \\
\hline $25 \%-50 \%$ & 125 & 53.0 & 57 & 24.2 & 61 & 25.9 \\
\hline $50 \%-100 \%$ & 23 & 9.8 & 13 & 5.5 & & 17 \\
\hline Don't know & 0 & 0 & 0 & 0 & 6 & 7.2 \\
\hline Total & 236 & 100 & 236 & 100 & 236 & 100 \\
\hline
\end{tabular}

Source: (Survey Questionnaire, 2021)

Business owners were also asked about the impact of the COVID crisis in the coming three months. About $10 \%$ of businesses felt that their business revenue will not be impacted for the three months to come. Whereas the majority, 139(59\%), and another $61(26 \%)$ of business owners have expected $0-25 \%$ and $25-50 \%$ revenue losses in the coming months, respectively. Concerning orders, $121(51 \%)$ of businesses expected not to experience the impacts of COVID in the next three months. But about $72(30 \%)$ of the businesses may face up to a $25 \%$ reduction in the business order they expect. Some 25 (11\%) of business owners feared a tougher reduction from $25 \%$ to $50 \%$ of orders. The results indicated that a COVID crisis was expected to affect revenue to the majority (85\%) of businesses; and orders of about $41 \%$ of businesses. It was identified that $117(50 \%)$ of businesses will not expect the impact of COVID crises in the workforce for the coming three months. However, about $40 \%$ of businesses 
would face downsizing their workforce. Some 73 (30.9\%) businesses could reduce their workforce size by up to $25 \%$, and an additional $21(9 \%)$ of businesses may reduce their workforce size by $25-50 \%$.

Table 5: Impact on business revenue, order and workforce in the coming three months

\begin{tabular}{|c|c|c|c|c|c|c|}
\hline & $\begin{array}{l}\text { Expected } \\
\text { COVID-19 } \\
\text { organizatio }\end{array}$ & $\begin{array}{l}\text { impact of } \\
\text { on } \\
\text { revenue }\end{array}$ & $\begin{array}{l}\text { Expected } \\
\text { COVID-19 } \\
\text { organizatio }\end{array}$ & $\begin{array}{l}\text { impact of } \\
\text { on } \\
\text { orders }\end{array}$ & $\begin{array}{l}\text { Expected } \\
\text { COVID-19 } \\
\text { organizatio } \\
\text { labor/workf }\end{array}$ & $\begin{array}{l}\begin{array}{l}\text { impact } \\
\text { on }\end{array} \\
\text { ce }\end{array}$ \\
\hline $\begin{array}{l}\text { Impact level in the } \\
\text { coming three months }\end{array}$ & Frequency & Percent & Frequency & Percent & Frequency & Percent \\
\hline None & 23 & 9.8 & 121 & 51.3 & 117 & 49.5 \\
\hline $0 \%-25 \%$ & 139 & 59 & 72 & 30.3 & 73 & 30.9 \\
\hline $25 \%-50 \%$ & 61 & 25.6 & 25 & 10.6 & 21 & 9.0 \\
\hline $50 \%-100 \%$ & 0 & 0 & 1 & 0.4 & 1 & 0.4 \\
\hline Don't know & 13 & 5.5 & 17 & 7.2 & 24 & 10.2 \\
\hline Total & 236 & 100 & 236 & 100 & 236 & 100 \\
\hline
\end{tabular}

Source: (Survey Questionnaire, 2021)

It was reported by $122(52 \%)$ of businesses faced difficulties in operating their business due to COVID-19. Among these businesses $104(79 \%)$ had experienced a shortage of supplies and input materials; hence they were not able to generate revenue and deliver orders due to the pandemic. Some $20(15.5 \%)$ of businesses had faced a shortage of cash flow, while $3(2.3 \%)$ had experienced difficulty in shipping finished goods. The industry of food and beverages manufacturing, which employs about $39 \%$ of the employees in the large and medium scale manufacturing sector, may also be affected due to reduction in production as a result of lack of imported raw materials, which constitutes $33 \%$ of its total input (CSA, 2018).

Table 5: Difficulty faced and the reasons for business difficulty

\begin{tabular}{|c|c|c|c|}
\hline & Frequency & Percent \\
\hline \multirow{3}{*}{$\begin{array}{l}\text { Have you faced difficulties so } \\
\text { far due to COVID-19? }\end{array}$} & No & 114 & 48.3 \\
\hline & Yes & 122 & 51.7 \\
\hline & Total & 236 & 100.0 \\
\hline \multirow{4}{*}{$\begin{array}{l}\text { If Yes for above question, what } \\
\text { are these difficulties? }\end{array}$} & Shortage of supplies/input materials & 104 & 78.8 \\
\hline & Shipping of finished goods & 3 & 2.3 \\
\hline & Shortage of cash flow & 20 & 15.5 \\
\hline & Total & 127 & 96.2 \\
\hline \multirow{3}{*}{$\begin{array}{l}\text { Do you face shortage of } \\
\text { workers? }\end{array}$} & No & 199 & 84.3 \\
\hline & Yes & 37 & 15.6 \\
\hline & Total & 136 & 100.0 \\
\hline \multirow{5}{*}{$\begin{array}{l}\text { If Yes for above question, what } \\
\text { are the reasons? }\end{array}$} & Workers are infected with COVID-19 & 28 & 66.7 \\
\hline & Workers staying away afraid of getting infected & 6 & 14.3 \\
\hline & $\begin{array}{l}\text { Workers are restricted in their Movement or } \\
\text { quarantined }\end{array}$ & 7 & 16.7 \\
\hline & Workers are taking care of family & 1 & 2.3 \\
\hline & Total & 42 & 100.0 \\
\hline
\end{tabular}

\section{Source: (Survey Questionnaire, 2021)}

About $37(15.6 \%)$ businesses were found to have been affected by the difficulties in finding the required workforce due to the COVID crisis. Most of them, 28(66.7\%), were not available at work for being infected by COVID. Other about $14(30 \%)$ of workforces may refrain from the work area fearing COVID infection or quarantined/caring family. Further, it was depicted in table 6 below that businesses with 10-50 employees before the crisis was 59 (25\%); which however reduced to $22(9.3 \%)$ of businesses with the required workforce size. This indicated that $36(15 \%)$ of businesses had operated their business with a reduced number of workforces. That is, they had experienced unemployment in part of their workforce. This unemployment was $40-70 \%$ of employees to severely affected $14(7 \%)$ of businesses. 
Table 6: Workforce employment status before and after the crisis

\begin{tabular}{|c|c|c|c|}
\hline & & Frequency & Percent \\
\hline \multirow{3}{*}{$\begin{array}{l}\text { Number of workers before the crisis in your } \\
\text { organization/enterprise }\end{array}$} & Below 10 & 177 & 75 \\
\hline & 10 to 50 & 59 & 25 \\
\hline & Total & 236 & 100.0 \\
\hline \multirow{3}{*}{$\begin{array}{l}\text { Number of workers after the crisis in your } \\
\text { organization/enterprise }\end{array}$} & Below 10 & 214 & 90.7 \\
\hline & 10 to 50 & 22 & 9.3 \\
\hline & Total & 236 & 100.0 \\
\hline \multirow[t]{5}{*}{ Percentage of unemployment due to COVID-19 } & $\mathrm{N} / \mathrm{A}$ & 51 & 25.1 \\
\hline & $0-20 \%$ & 80 & 39.4 \\
\hline & $20-40 \%$ & 58 & 28.6 \\
\hline & $40-70 \%$ & 14 & 6.9 \\
\hline & Total & 203 & 86.0 \\
\hline
\end{tabular}

\section{Source: (Survey Questionnaire, 2021)}

For $58(28.6 \%)$ of businesses employment figures were downsized by $20-40 \%$. Considerably large numbers of businesses ( 80 or $39.4 \%$ ) were experienced up to $20 \%$ of absentees' workforces. Generally, regardless of their sizes, about $75 \%$ of businesses had experienced a reduction in their existing workforces. An analysis of paired sample t-test was conducted to see income changes of businesses. It was computed that the average income businesses lost during the pandemic were birr 3,687.60 that was a significant ( $\mathrm{p}$-value $<0.05)$ change in income, which ranged in the $95 \%$ CI of 2832-4543.

Table 7: Comparison of Revenue before and after the crisis in the businesses

\begin{tabular}{|c|c|c|c|c|c|c|c|c|c|c|c|}
\hline & \multirow[t]{3}{*}{ Mean } & \multirow[t]{3}{*}{$\mathrm{N}$} & \multirow{3}{*}{$\begin{array}{l}\text { Std. } \\
\text { Deviation }\end{array}$} & \multirow{3}{*}{ 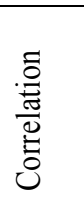 } & \multicolumn{4}{|c|}{ Paired Differences } & \multirow[t]{3}{*}{$\mathrm{t}$} & \multirow[t]{3}{*}{$\mathrm{Df}$} & \multirow{3}{*}{$\begin{array}{l}\mathrm{p}- \\
\text { value }\end{array}$} \\
\hline & & & & & \multirow[t]{2}{*}{ Mean } & \multirow[t]{2}{*}{$\begin{array}{l}\text { Std. } \\
\text { Deviation }\end{array}$} & \multicolumn{2}{|c|}{$\begin{array}{l}95 \% \text { Confidence } \\
\text { Interval of the } \\
\text { Difference }\end{array}$} & & & \\
\hline & & & & & & & Lower & Upper & & & \\
\hline $\begin{array}{l}\text { How much } \\
\text { was your } \\
\text { monthly } \\
\text { income before } \\
\text { COVID-19 } \\
\text { crisis (in birr)? }\end{array}$ & 8900.85 & 236 & 8922.73 & 0.675 & 3707.4 & 6628.76 & 2857.32 & 4557.50 & 8.59 & 235 & 0.000 \\
\hline $\begin{array}{l}\text { How much } \\
\text { was your } \\
\text { monthly } \\
\text { income after } \\
\text { COVID-19 } \\
\text { crisis (in birr)? }\end{array}$ & 5193.43 & 236 & 6770.48 & & & & & & & & \\
\hline
\end{tabular}

\section{Source: (Survey Questionnaire, 2021)}

The table below 8 described the changes in revenue before and after the COVID-19 crisis. It was found that business owners could receive income of birr 8,900.85 monthly before the pandemic; which, however, now reduced to birr $5,193.43$ on average. The average income loss by business owners was $41.7 \%$ during the crisis. 
Table 8: Impact of COVID-19 on Business Revenue by Sector

\begin{tabular}{|c|c|c|c|c|}
\hline $\begin{array}{l}\text { Sector the sample } \\
\text { individual is engaged in }\end{array}$ & Statistic & $\begin{array}{l}\text { Revenue before } \\
\text { COVID-19 crisis (in } \\
\text { birr) }\end{array}$ & $\begin{array}{l}\text { Revenue after } \\
\text { COVID-19 crisis } \\
\text { (in birr) }\end{array}$ & $\begin{array}{c}\text { percentage of } \\
\text { Business Revenue } \\
\text { declined }\end{array}$ \\
\hline \multirow[t]{5}{*}{ Service } & Mean & 5042.34 & 2874.60 & $43 \%$ \\
\hline & Minimum & 500.00 & 200.00 & $60 \%$ \\
\hline & Maximum & 30000.00 & 13500.00 & $55 \%$ \\
\hline & $\begin{array}{l}\text { Std. } \\
\text { Deviation }\end{array}$ & 6562.71 & 4936.23 & $25 \%$ \\
\hline & $\mathrm{N}$ & 124 & 124 & \\
\hline \multirow[t]{5}{*}{ Manufacturing } & Mean & 6355.81 & 3800.00 & $40 \%$ \\
\hline & Minimum & 500.00 & 200.00 & $60 \%$ \\
\hline & Maximum & 20000.00 & 12000.00 & $40 \%$ \\
\hline & $\begin{array}{l}\text { Std. } \\
\text { Deviation }\end{array}$ & 5001.82 & 3086.22 & $38 \%$ \\
\hline & $\mathrm{N}$ & 43 & 43 & \\
\hline \multirow[t]{5}{*}{ Construction } & Mean & 17421.01 & 10228.99 & $41 \%$ \\
\hline & Minimum & 1600.00 & 350.00 & $78 \%$ \\
\hline & Maximum & 30500.00 & 22000.00 & $28 \%$ \\
\hline & $\begin{array}{l}\text { Std. } \\
\text { Deviation }\end{array}$ & 10521.78 & 6153.51 & $42 \%$ \\
\hline & $\mathrm{N}$ & 69 & 69 & \\
\hline \multirow[t]{5}{*}{ Total } & Mean & 8900.85 & 5193.43 & $42 \%$ \\
\hline & Minimum & 500.00 & 200.00 & $60 \%$ \\
\hline & Maximum & 30500.00 & 22000.00 & $28 \%$ \\
\hline & $\begin{array}{l}\text { Std. } \\
\text { Deviation }\end{array}$ & 8922.73 & 6770.48 & $24 \%$ \\
\hline & $\mathrm{N}$ & 236 & 236 & \\
\hline
\end{tabular}

\section{Source: (Survey Questionnaire, 2021)}

Looking into businesses by each sector, the service sector lost $43 \%$ of their revenue during the pandemic; while the manufacturing and construction sectors lost $40 \%$ and $41 \%$ of their potential revenues, respectively. Looking into individual data, the maximum revenue loss experienced by the service sector was $93 \%$ in some cases which are relatively larger compared to the highest revenue losses by manufacturing $(71 \%)$ and construction $(78 \%)$. As cited by Fentahun and Wuhibegezer, 2020 reported by the Economic Response Plan crafted by the Commission suggests that the effects of the COVID pandemic are expected to heavily impact the manufacturing and construction sectors and the possibility that over 552,000 jobs on average will be lost within three months.

\section{Conclusion}

The study aimed to investigate the socio-economic effects of the COVID-19 pandemic on service, manufacturing, and construction sectors in the Gurage zone. The finding from the study indicated that the crises brought great and unexpected effects on the people who employed and invested in the service, manufacturing, and construction sectors. In contrast, the business environments of the service, manufacturing, and construction sectors were adversely affected due to the COVID-19 pandemic. A significant amount of reduction in revenues orders and labor force were comprehended in these businesses. In addition, businesses faced a high shortage of raw materials, limited access to transportation of goods, a decrease in the number of customers, and goods were expired during the crises. The COVID-19 remains a serious threat to the people of the world, Africa, and, most specifically Ethiopia. Thus, a careful policy measure to confront the pandemic is highly needed. Based on the findings of the study, the researchers forwarded the following recommendations. These are:

As designated in this study the COVID-19 threatened the lives of people working in small businesses such as service, manufacturing, and construction sectors. Thus, designing a well-defined social protection scheme by the policymakers to make sure that the workers maintain their socio-economic welfare is mandatory. To minimize the adverse effect of the crises, the government should focus on providing continuous education and information to the public on how the pandemic spreads and what protective measures can be taken.

The finding also showed that business owners in the service, manufacturing, and construction sectors are adversely affected by COVID-19 crises in terms of their revenues. So, the government body and policymakers should facilitate lower interest credits to most affected business firms to maintain their businesses. Since the disruption from this pandemic is high and sustains for a longer period, promoting cooperation and solidarity among people is very essential. 


\section{References}

Boissay F. and Rungcharoenkitkul P. (2020), Macroeconomic effects of Covid-19: an early review, BIS Bulletin No. 7, WB, 2020.

CSA (2013).Population Projection of Ethiopia for All Regions at district level from 2014-2017. Addis Ababa, Ethiopia: Central Statistics Agency (CSA).

Evans. D., (2020). "How Will COVID-19 Affect Women and Girls in Low- and Middle-Income Countries?" Available at https:/www.cgdev.org/blog/how-will-covid-19-affect-women-and-girls-low-and-middleincomecountries.

Forsido SF, Mitiku F, Lemessa F, Tolemariam T, Belew D, Berecha G, Garedew W, Bekele Y, Geda F and Eneyew A (2020). COVID-19 Probable Impacts on Ethiopian Agriculture and Potential Mitigation and Adaptation Measures: No Food-No Health-No Life. Jimma, Ethiopia: Jimma University, 2020.

GoshuD., Ferede T., Diriba G., and Ketema M. (2020) Economic and welfare effect of Covid-19 and response in Ethiopia; Insights, EEPRI.

ILO (2013), Perspectives on Labour Economics for Development: Chapter four-Informality, ILO, Geneva.

ILO (2020), the impact of COVID-19 on the informal economy in Africa and the related policy responses, ILO Brief, 14-April-2020

ILO. (2020). COVID-19 and world of work: Impacts and responses, Geneva.

IMF (2020): https://www.weforum.org/agenda/2020/04/imf-economy-coronavirus-covid-19 recession

UNCTAD (2020), Coronavirus Shock: A Story of another Global Crisis Foretold and What Policy Makers Should is doing about it? Trade and Development Update, UNCTAD/GDS/INF/2020/1

UNECA (2020), COVID-19 in Africa: Protecting Lives and Economies, COVID-19 Response, ECA, Addis Ababa, Ethiopia.

UNECA (2020).Economic Effects of the COVID-19 on Africa United Nations Economic Commission for Africa (UNECA), Addis Ababa, Ethiopia.

UNIDO (2020), Coronavirus: the economic impact: Which countries and manufacturing sectors are most affected by the COVID-19 crisis? Some early evidence and possible policy responses

WB (2020), Assessing the Economic Impact of Covid-19 and Policy Responses in Sub-Saharan Africa, African Pulses April, 2020, Volume 21, WB, Washington DC.

Weber A. (2020), Covid-19 in the Horn of Africa: Gaining Trust in a Crisis, SWP Comment, No. 20, May, 2020. 